\title{
足部接地パターンがランニングにおける 推進特性に及ぼす影響
}

\author{
Effect of Foot Strike Pattern on Propulsion in Running
}

\author{
肥田 直人 ${ }^{1)}$ 石井 慎一郎 ${ }^{2)}$ 山本 澄子 ${ }^{3)}$ \\ NAOTO HIDA, RPT ${ }^{1)}$, SHINICHIRo ISHII, $\mathrm{PhD}^{2)}$, SUMIKo YAMAMOTO, $\mathrm{PhD}^{3)}$ \\ ${ }^{1)}$ Honmoku Hospital: 11-5 Honmokusannotani, Naka-ku, Yokohama-shi, Kanagawa 231-0824, Japan TEL +81 45-621-2445 \\ E-mail:15s3054@g.iuhw.ac.jp \\ ${ }^{2)}$ Kanagawa University of Health and Welfare Graduate School \\ ${ }^{3)}$ International University of Health and Welfare Graduate School
}

Rigakuryoho Kagaku 31(6): 815-818, 2016. Submitted May 16, 2016. Accepted Jul. 8, 2016.

\begin{abstract}
Purpose] This study investigated differences in forefoot and hindfoot strike patterns on propulsion in running. [Subjects and Methods] The subjects were 18 healthy adults. Forefoot strike running (FR) and hindfoot strike running (HR) were measured using a 3D motion analysis system. [Results] In HR, forward transfer of the center of gravity in the stance phase was large, whereas it was large in the swing phase of FR. In HR, the vertical component of the ground reaction force (GRF) was large in the first half of the stance phase, and in FR, the vertical and anterior components of GFR were large in the latter half. In HR, a large torque was generated in the posterior direction in the first half of the stance phase. [Conclusion] It was found that in HR, forward propulsion was generated through reduction of the impact of heel strike, whereas in FR, it was generated by striking the ground hard.
\end{abstract}

Key words: running, foot strike pattern, propulsion

要旨：〔目的〕本研究では, ランニングに扔ける前足部接地と後足部接地の推進特性の違いを調べた。【対象と方法〕 対象は健常成人 18 名. 三次元動作解析装置を用いて前足部から接地したランニングと, 後足部から接地したランニ ングを計測した。〔結果〕後足部接地では立脚期に重心前方移動が大きく，前足部接地では遊脚期に大きかった。後 足部接地では立脚前半における床反力鉛直成分が大きく，前足部接地では立脚後半における床反力鉛直・前方成分が 大きかった，後足部接地では，立脚前半に大きな後方への回転力が生じた。〔結語〕後足部接地では衝撃を減らすこ とで前に進み，前足部接地では地面を強く蹴ることで前に進むという特性がみられた.

キーワード：ランニング, 足部接地パターン, 推進

\footnotetext{
1) 本牧病院：神奈川県横浜市中区本牧三之谷 11-5 († 231-0824) TEL 045-621-2445

2) 神奈川県立保健福祉大学大学院

3) 国際医療福祉大学大学院

受付日 2016 年 5 月 16 日受理日 2016 年 7 月 8 日
} 


\section{I. はじめに}

これまで, ランニングの足部接地パターンは, 後足部 接地（rearfoot strike, 以下 RFS）が一般的であり，一 般のマラソンランナーを調査した研究においても全体の 98.12\%ものランナーがRFS を選択していたとの報告が なされている1). しかし，近年のマラソン競技において 速いタイムを出しているケニアやエチオピアの選手は前 足部部地（forefoot strike, 以下 FFS）を選択する傾向に あり, マラソンの世界記録保持者でケニア出身の選手も

FFS であったことが報告されている2).

RFS とFFS に関しては，常にランニングシューズを 着用して走るランナーはRFS を選択し, 対照的に東ア フリカのランナーのように常に裸足で走る習慣のあった 長距離ランナーはFFS を選択すること，またFFSでは 接地時の衝撃力が少ないとの報告がなされている ${ }^{3)}$. そ のため, 日本人のようにクッション性の良い靴を履いて 育ったランナーは, 靴を履くことで着地時の衝撃を軽減 させているが, 東アフリカのランナーのように靴を履か ないで育ったランナーは, 自然に FFS を選択して衝撃 を軽減させていることが推察される.

FFS が足部接地時の衝撃が少ない理由として, 吉野 4) はFFSでは接地時の衝撃を足のアーチやアキレス腱, ふくらはぎの筋肉などで吸収できるからだと述べてい る.このような考えから，ランニングではRFSよりも 接地時の衝撃が少ないFFSの方が適しているという考 えが広まってきている，それに伴い，靴を履いて育った ランナーにおいても, あえて FFS を選択するランナー が増加している.しかし，FFSに意識的に変更したラン ナーにおいて第 2 中足骨の疲労骨折を呈したとの報告 5) や, FFS ではシンスプリントの発生リスクが高まるとの 報告6) がなされており, RFS と FFSのどちらの足部接 地パターンが良いのかは現在も議論がなされている。

これらの報告から, 足部接地パターンは生まれ育った 環境に多大な影響を受けることが示唆された。しかし， ランニングとは, 左右の足で交互に地面を蹴ることに よって前方に移動する動きであり7), RFS と FFS では この重心を前方に推進させるためのメカニズムの違いは 明らかにされておらず，どのようなランニングフォーム にRFS やFFS が適しているのかは定かではない. そこ で，本研究では RFS と FFSにおける前方に移動するた めの推進特性の違いを明らかにするため, 運動力学の観 点から並進運動と回転運動に着目して分析を行った。

\section{II. 対象と方法}

\section{1. 対象}

被検者は，本研究の趣旨および目的に対して，同意が 得られた健常成人 18 名（男性 14 名, 女性 4 名）とした。
被検者の除外基準は, 既往歴に整形外科的疾患, 重篤な 呼吸器・循環器疾患, 皮膚疾患被検者がない者とした。 被検者の年齢は $25.9 \pm 3.7$ 歳であり, 身長は $168.6 \pm$ $5.5 \mathrm{~cm}$, 体重は $60.8 \pm 7.2 \mathrm{~kg}$ (平均值 \pm 標準偏差）で あった。

なお, 本研究は神奈川県立保健福祉大学大学院の倫理 審査委員会の承認（承認番号 25-035）を得て行われた。

2. 方法

ランニングの計測は，6枚の床反力計（AMTI 社製） と 10 台の赤外線カメラで構成される三次元動作解析装 置（VICON612，VICON-PEAK 社製）を用いて行った。

被検者の体表面上の所定の位置に, 臨床歩行分析研究 会の提唱するDIFF 方式 8) に準じて, 赤外線反射標点を 貼付した. 赤外線反射標点の貼付位置は, 両側の肩峰, 右肩甲骨下角，両側の上前腸骨棘と大転子を結んだ線の $1 / 3$ の点, 両側の膝関節裂隙外側, 両側の外果, 両側の 第 5 中足趾節間関節の計 11 箇所とした.

運動課題は 2 種類あり, 後足部から接地したランニン グの RFS を計測した後に, 前足部から接地したランニ ングの FFS の計測を行った. RFS と FFS の両条件で, 計測装置が接地された $8 \mathrm{~m}$ の走行路を, 被検者が走り やすいと感じる速度で, 意識的に後足部ないし前足部か ら接地するよう指示した。 また, 被検者には計測を行う 前にRFS と FFS という二つの異なった足部接地パター ンに慣れることができるよう, 十分に練習する時間を与 えた。

三次元動作解析装置によってサンプリングされた, 各赤 外線反射標点の三次元座標データと床反力データを, 計 算処理プログラム DIFF Gait と Wave Eyesを使用して計 算処理を行い, 重心移動距離, 床反力鉛直 - 前後成分, 身体重心回りのモーメントを算出した。また本研究では, 床反力前後成分を用いて立脚期を立脚前半, 立脚後半に 分けた. 立脚前半は足部接地から床反力前後成分が後方 から前方に切り替わるまでとし, 立脚後半は床反力前後成 分が前方に切り替わった時期からつま先離地までとした。

重心移動距離の分析では，立脚期において重心が前方 に移動した距離と, 遊脚期において重心が前方に移動し た距離を算出し，その值をランニング中の平均速度で除 し，速度を一定と仮定したときの立脚期と遊脚期におけ る移動距離を算出した。

床反力の鉛直成分の分析では，立脚前半における鉛直 成分の積分值, 立脚後半における鉛直成分の積分值を算 出した．床反力の前後成分の分析では，立脚前半におけ る後方成分の積分值, 立脚後半における前方成分の積分 值を算出した。

身体重心回りのモーメント（以下，身体回転力）の分 析では, 矢状面内の重心位置と床反力作用点 (center of pressure, 以下 COP) 位置（前後方向位置）, 床反力前 
後・鉛直成分より, 以下の計算式を用いて算出した. 身体回転力 $=F y \times d z+F z \times d y （$ 図 1）

$F y$ : 床反力前後成分

$d z:$ 重心の高さ

$F z$ : 床反力鉛直成分

$d y$ : 重心と COP の前後方向座標位置の差から算出し た距離

上記計算式によって算出した身体回転力のデータから， 立脚前半における後方への身体回転力のピーク值を算出 した。

統計学処理では, RFS と FFS それぞれの各 5 試行の 計測データの平均值を代表データとし, 対応のある $\mathrm{t}$ 検 定を用いて RFS と FFS における代表データの差を比較 した，有意水準は $5 \%$ とした。統計ソフトはJSTATを 使用した。

\section{III. 結 果}

立脚期の重心前方移動距離は, RFS がFFSに比較し て有意に大きかった $(\mathrm{p}=0.01)$. 一方, 遊脚期の重心前 方移動距離はFFS が RFS に比較して有意に大きかった $(\mathrm{p}=0.02)$.

床反力鉛直成分の積分值は，立脚前半では RFS が FFS より有意に大きく $(\mathrm{p}=0.01)$, 立脚後半では FFS がRFSより有意に大きかった $(\mathrm{p}=0.01)$. 床反力前後 成分の積分值は, 立脚前半の床反力後方成分には有意な 差はみられなかったが $(p=0.45)$, 立脚後半における床 反力前方成分では FFS がRFSより有意に大きかった $(\mathrm{p}=0.01)$.

身体回転力は, 立脚前半において RFS では FFS より有 意に大きな後方への回転力が出現した $(\mathrm{p}=0.01)$ （表 1$)$.

\section{IV. 考 察}

ランニングの重心移動様式は,「はずむボール (bounding ball)」のような重心の軌跡をたどることが知 られており9), 重心は足部接地後に前下方に移動し最下 点に達すると, その後は前上方に移動し足部離地後の遊 脚期に最上点に達する。本研究結果においても，RFS と FFS ともに,「はずむボール」の重心の軌跡となった.

一方, RFS と FFS では重心を前方移動するための推進 特性が異なることがわかった，RFSでは身体の回転を 制動しながら立脚期に重心を前方に推進させているのに 対して, FFSでは跳び跳ねるように前方に推進して いた。

RFS が立脚期に大きく前に進むことができた理由と して, RFS では立脚前半において大きな床反力鉛直成 分が生じていたことが考えられる．立脚前半において大 きな床反力鉛直成分が生じることで，重心には持ち上げ るような力が加わるのと同時に, 立脚前半では COP が 重心よりも前方に位置しているため大きな後方への回転 力が生じることになる. ランニングでは足部が地面に接

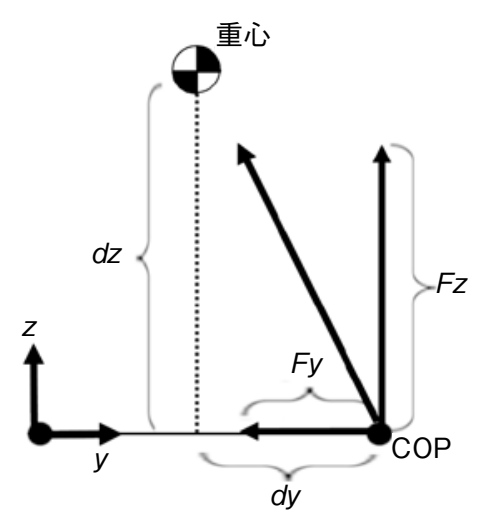

図1 矢状面における重心とCOP, 床反力の力学モデル

表 1 RFS 条件と FFS 条件での比較

\begin{tabular}{lcc}
\hline & RFS & FFS \\
\hline 重心移動距離 (移動距離/平均速度) & & \\
立脚期 & $0.25 \pm 0.05$ & $0.24 \pm 0.04^{*}$ \\
遊脚期 & $0.12 \pm 0.04$ & $0.14 \pm 0.04^{*}$ \\
床反力鉛直成分 積分值 (Ns) & & \\
鉛直成分 立脚前半 & $120.2 \pm 19.3$ & $98.5 \pm 15.0^{*}$ \\
鉛直成分 立脚後半 & $89.0 \pm 15.0$ & $108.6 \pm 19.8^{*}$ \\
後方成分 立脚前半 & $10.7 \pm 2.5$ & $10.4 \pm 2.2$ \\
前方成分 立脚後半 & $13.2 \pm 2.6$ & $17.4 \pm 3.9^{*}$ \\
身体後方回転力 ピーク值 (Nm) & & \\
立脚前半 & $30.4 \pm 20.6$ & $12.2 \pm 20.1^{*}$ \\
\hline
\end{tabular}

数值は平均值 \pm 標準偏差. RFS : rearfoot strike, FFS : forefoot strike.

$*: \mathrm{p}<0.05$. 


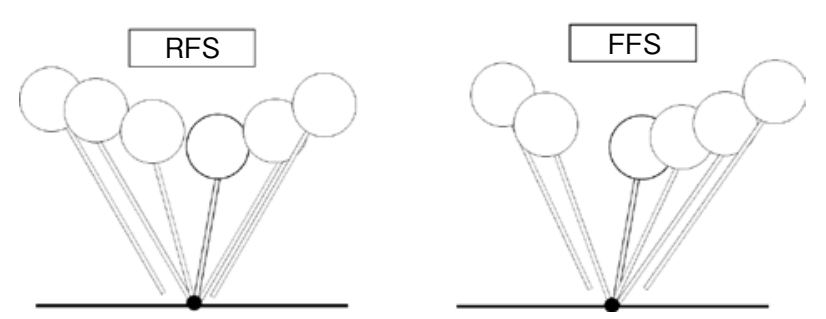

図2 後足部接地と前足部接地における重心前方移動様式の 違い

地する瞬間には重心は前方への速度を持っていることか ら，足部接地後には慣性により重心は前方に進んでいき， 重心は足関節を支点として前方に回転していく，そのた め, RFS では立脚前半に後方への身体回転力を大きく することで，慣性により生じる重心の前方回転にブレー キをかけていることが考えられる，RFSでは立脚前半 の重心が下がっていく期間において，重心を持ち上げる 力を生じるのと同時に慣性による前方回転にブレーキを かけることで，重心が落下するまでの時間が延長され， その期間に大きく前方に移動するという推進特性を用い

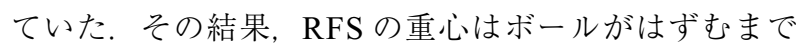
の間に大きく前方に移動し，はずむ距離は短くなってい たことが示唆される (図 2)。本研究結果から, 臨床現 場において, RFS では歩幅を長くとるストライド走行 がより適していることが示唆される.

一方，FFS では，遊脚期に大きく前に進むという戦略 を取っていた．FFS が遊脚期に大きく前に進むことがで きた理由として，足部接地時の衝撃が小さいことが挙げ られる. FFS では立脚前半の床反力鉛直成分（足部接地 時の衝撃）が小さいことで，慣性による前方回転を打ち 消すことなく重心が円滑に前方に回転していき，素早く 立脚後半に移行していた。 その後の立脚後半において FFS では床反力鉛直成力・前方成分を大きくし，地面を 強く蹴ることで遊脚期に重心を大きく前方に移動すると いう推進特性を用いていた。 その結果, FFSの重心は, ボールが大きく前にはずむような動きとなっていたこと が示唆される (図 2).これらから, 臨床現場において, FFS では, 立脚時間が短く素早く足を回転させるピッチ
走行が適していることが示唆される.

また，本研究結果から，RFSでは大きな衝撃を利用 し慣性による前方回転力を打ち消すことで, 立脚期に大 きく前方に進むという特性がみられた。一方，FFSでは 衝撃を少なくし慣性により円滑に前方に回転し, 立脚後 半において蹴り出す力を大きくすることで，遊脚期に大 きく前方に進むという特性がみられた，RFS とFSで は推進特性が違うため, 臨床現場ではRFS と FFSのそ れぞれの特性を考慮したランニングフォームを指導する ことが重要である.

本研究の限界として, 三次元動作解析装置を使用した ことで走行路が $8 \mathrm{~m}$ と短くなったことや，被検者に研究 のために足部接地パターンを矯正したことで，普段とは 異なったランニングとなった可能性が示唆される。今後 は, 十分な走行路を確保することや，被検者の普段の足 部接地パターンを考慮したうえでの検証が必要と考える.

\section{引用文献}

1) Bertelsen ML, Jensen JF, Nielsen MH, et al.: Footstrike patterns among novice runners wearing a conventional, neutral running shoe. Gait Posture, 2013, 38(2): 354-356.

2) NHKスペシャル取材斑, 善家 賢: $42.195 \mathrm{~km}$ の科学. 角 川書店，東京，2013, pp98-99.

3) Lieberman DE, Venkadesan M, Werbel W, et al.: Foot strike patterns and collision forces in habitually barefoot versus shod runners. Nature, 2010, 463(7280): 531-535.

4) 吉野 剛: 新走法で速くなる! 裸足感覚ランニング. 洋泉社, 東京, 2013, p18.

5) Giuliani J, Masini B, Alitz C, et al.: Barefoot-simulating footwear associated with metatarsal stress injury in 2 runners. Orthopedics, 2011, 34(7): 320-323.

6) 笹山亜紗子, 松本秀男, 世良 泰・他：前足部及び後足部 接地により歩行及びランニング時の下腿障害リスクは増加 するか. 臨床バイオメカニクス，2010,31: 469-475.

7) 谷川英徳:ランニングのバイオメカニクス. 臨床スポーツ医学, 2014, 31(9): 824-829.

8) 櫻井愛子：臨床歩行計測入門. 江原義弘 - 他 (編), 医歯薬 出版, 東京, 2002, pp150-153.

9) 小田伸午, 市橋則明：ヒトの動き百話. 市村出版, 東京, 2011, p162. 